\title{
Effect of COVID-19 on the Mental Health and Social Activities of Healthcare Students in Southwestern Nigeria
}

\author{
Edidiong Orok ${ }^{1 *}$ (D), Success David ${ }^{2}$ (D) Tofunmi Olajide $^{3}$ (D), Adesina Sulaiman ${ }^{3}$ (D), \\ Ebunoluwa Oyewole ${ }^{4}$ (D) \\ ${ }^{1}$ Department of Clinical Pharmacy and Pharmacy Administration, University of Ibadan, Ibadan, Nigeria \\ ${ }^{2}$ Faculty of Pharmacy, University of Nigeria, Nsukka, Nigeria \\ ${ }^{3}$ Faculty of Nursing Sciences, Ladoke Akintola University of Technology Osogbo, Osun State, Nigeria \\ ${ }^{4}$ Department of Medical Laboratory Sciences, Adeleke University, Osun State, Nigeria \\ * Corresponding author: Edidiong Orok E-mail: pharmorok@gmail.com ORCID: 0000-0002-5273-1927 \\ Received: 9 June 2020 Accepted: 31 July 2020
}

\begin{abstract}
COVID-19 has been predicted to cause mental health deterioration among inhabitants around the globe including university students. This study was aimed at evaluating the perceived effect of COVID-19 on the mental health and social activity of healthcare students in southwestern Nigeria. A cross-sectional online survey method was used in the evaluation where an online questionnaire was distributed to the Whatsapp groups of undergraduate and post-graduate healthcare students from May to June 2020 using convenience sampling technique. Data were analysed using Statistical Package for Social sciences version 25 and results were presented using descriptive statistics which included mean, frequencies and percentages. Inferential statistics was done using the chi-square analysis. A total of 261 students consented to participate in the study. The mean age of the respondents was $23.77 \pm 3.85$ years from various disciplines including pharmacy (31.4\%), nursing (31\%) and medicine (21.1\%). Majority of the respondents $(69.7 \%, 95 \%, 64.4 \%$ and $96.6 \%)$ had more than $50 \%$ perceived effect score showing considerable effect of COVID-19 on mental health, social life, safety and formal learning respectively. There was an association between gender and the perceived effect of COVID-19 on mental health and safety. There was no association between gender and perceived effect of COVID-19 on formal learning and social activity. COVID19 has a considerable effect on mental health and social activity of healthcare students. There is a need for interventions to help reduce the effect of COVID-19 on mental health and encourage the use of online platforms to improve learning among college students.
\end{abstract}

Keywords: COVID-19, healthcare students, mental health, social activities, Nigeria

\section{INTRODUCTION}

Coronavirus outbreak has cut across many countries and is known to be a global pandemic which originated from
Wuhan, China in December 2019 [1,2]. Coronavirus, which was initially identified as SARS COV2 (Severe Acute Respiratory Syndrome Coronavirus) before being called Coronavirus Disease (COVID-19), is a highly contagious

@ 2020 by the authors; licensee EJMETS by Bastas, UK. This article is an open access article distributed under the terms and conditions of the Creative Commons Attribution License (http://creativecommons.org/licenses/by/4.0/). 
pathogen that can affect all ages [3,4]. However, the elderly and people with underlying medical conditions have been reported to be at higher risk of getting severe symptoms of the disease [1].

COVID-19 outbreak has not only contributed to an increase in death rate, dwindling economies and businesses in a number of countries including African countries [5,6] but has also been predicted to cause mental health deterioration due to psychological pressure, anxiety, fear and worry among inhabitants around the world including college students [7]. Measures such as the social distancing and total shut down of universities has been so far applied and this has been anticipated to affect the mental health and social wellbeing of students [7].

Coronavirus disease (COVID-19) pandemic has affected a lot of sectors and lives including students around the world [8]. The effect of COVID-19 on mental health of people has been well documented in several studies including studies in China $[9,10]$ and in Italy $[11,12]$ where it has been exclusively studied. Studies have also been documented on the effect of COVID-19 on college students including their mental health in developed countries such as China [13-15] and Greece [16] as well as in developing countries such as India [17]. The effect of COVID-19 has also been predicted among inhabitants in the US and UK $[18,19]$. No study has been documented to the best of our knowledge on the effect of COVID-19 on the mental health and social activity of healthcare students in Nigeria. This study will aim to provide baseline information about the effect of coronavirus on the mental and social activity of healthcare students in south west Nigeria. The findings from this research will help in the design of effective measures that will help boost the mental and social wellbeing of students.

\section{General Objective}

To evaluate the perceived effect of COVID-19 on the mental health and social activity of healthcare students in southwestern Nigeria

\section{MATERIALS AND METHODS}

\section{Research Design}

The research method was cross-sectional online survey. No variables were manipulated but were described as occurred in the study. The study was carried out from May 2020 to June 2020

\section{Study Population}

The study population used for this research was undergraduate and post-graduate healthcare students in southwestern Nigeria.

\section{Sample Size Determination}

The sample size was calculated using the Raosoft online calculator (www.raosoft.com/samplesize) from an estimated total population of 20,000 to be 377 .

\section{Sampling Technique}

Convenience sampling technique from federal and state universities in Southwest Nigeria was used to sample the consenting participants.

\section{Instrumentation for Data Collection}

The type of instrument used in carrying out this research was self-designed online questionnaire. It was divided into 5 sections. The first section is on demographic data with 4 items while the remaining four sections were measured using the Likert scale of measurement. The second section was on the effect of COVID-19 on the mental health of healthcare students with 3 items. The third section was on effect of COVID-19 on the social life of healthcare students with 3 items and the fourth section was on the effect of COVID-19 on the safety of healthcare students with 3 items. The fifth section was on the effect of COVID-19 on the formal learning of healthcare students with 3 items.

\section{Validity and Reliability of Instrument}

The questionnaire used in this study was validated through face validity and content validity among lecturers in the department of Clinical Pharmacy and department of nursing with expertise in the field of research. The reliability of the questionnaire was also tested via a pre-test in 20 healthcare students that were not included in the main study and the Cronbach alpha value obtained from the pre-test was 0.72 .

\section{Data Collection}

An online questionnaire was distributed to the WhatsApp groups of the undergraduate and post-graduate healthcare students from federal and state universities in southwestern Nigeria. The consent of each student in the WhatsApp groups was sought before distribution of the online questionnaire. The questionnaire was designed such that it took a minimum of 2 minutes to complete.

\section{Informed Consent}

The online questionnaire was designed such that the scope of the study was explained after which a question of consent 
Table 1. Socio-demographic parameters of study participants

\begin{tabular}{|c|c|c|c|}
\hline \multicolumn{2}{|c|}{ Variables } & $\begin{array}{c}\text { Frequency } \\
\text { (N =261) }\end{array}$ & Percent (\%) \\
\hline \multirow{2}{*}{ Gender } & Female & 146 & 55.9 \\
\cline { 2 - 4 } $\begin{array}{c}\text { Age } \\
\text { Mean } \pm \text { SD (range) }\end{array}$ & Male & 115 & 44.1 \\
\hline \multirow{3}{*}{ Ethnicity } & Hausa & 10 & 3.7 \\
\cline { 2 - 4 } & Igbo & 66 & 25.3 \\
\cline { 2 - 4 } & Others & 19 & 7.3 \\
\cline { 2 - 4 } & Yoruba & 166 & 63.6 \\
\hline \multirow{2}{*}{ Religion } & Christianity & 178 & 68.2 \\
\cline { 2 - 4 } & Islam & 83 & 31.8 \\
\hline \multirow{2}{*}{ Marital Status } & Married & 16 & 6.1 \\
\cline { 2 - 4 } & Single & 245 & 93.9 \\
\hline
\end{tabular}

$\mathrm{SD}=$ Standard Deviation

to participate in the study was posed to the participants. The participants that picked "yes" proceeded to the remaining part of the questionnaire while picking no marked the end of the survey.

\section{Data Analysis}

All data analysis was carried out using statistical package for social sciences (SPSS) version 25. The socio-demographic parameters were summarized using descriptive statistics. Age was summarized using mean \pm standard deviation while gender, marital status and other demographics were summarized using frequencies and percentages. Association between gender and perceived effect of COVID19 on mental health, gender and perceived effect of COVID19 on social life, gender and perceived effect of COVID-19 on safety as well as gender and perceived effect of COVID-19 on formal learning of healthcare students was analysed using the Pearson's chi-square test. Level of significance was set at 0.05 .

\section{Ethical Considerations}

The study was evaluated by the ethics review board and eventually approved. The study protocol was approved by the University College Hospital Ethics Committee, University College Hospital, Ibadan, Nigeria with approval number UI/EC/20/0133. The study was conducted in accordance with the ethical standards as laid down in the 1964 Declaration of Helsinki and its later amendments [20].

\section{Funding}

This research was a self-sponsored study
Table 2. Course of study and study level of respondents

\begin{tabular}{|c|c|c|c|}
\hline \multicolumn{2}{|r|}{ Variables } & Frequency & Percent \\
\hline \multirow{11}{*}{$\begin{array}{l}\text { Course } \\
\text { of study }\end{array}$} & Anatomy & 12 & 4.6 \\
\hline & Biochemistry & 3 & 1.1 \\
\hline & Biotechnology & 1 & 0.4 \\
\hline & Medical Laboratory Science & 14 & 5.4 \\
\hline & Medicine and Surgery & 55 & 21.1 \\
\hline & Microbiology & 2 & 0.8 \\
\hline & Nursing & 81 & 31.0 \\
\hline & Pharmacy & 82 & 31.4 \\
\hline & Physiology & 2 & 0.8 \\
\hline & Public health & 8 & 3.1 \\
\hline & Radiography & 1 & 0.4 \\
\hline \multirow{2}{*}{$\begin{array}{c}\text { Current } \\
\text { level of } \\
\text { study }\end{array}$} & Undergraduate (100-600 level) & 233 & 89.3 \\
\hline & $\begin{array}{c}\text { Post-graduate (MSc. And } \\
\text { Ph.D.) }\end{array}$ & 28 & 10.7 \\
\hline
\end{tabular}

\section{RESULTS}

\section{Socio-demographics, Course and Level of Study of Participants}

A total of 261 students from 22 universities that comprised of private and federal universities in Oyo, Ogun, Osun, Ondo, Ekiti, Lagos states consented to participate in this study with majority 146 (55.9\%) of the respondents being female while the remaining 115 (44.1\%) were male. The mean age of the respondents is $23.77 \pm 3.85$ years with the minimum age of 18 years and maximum age of 55 years. Based on their ethnicity, most $166(63.6 \%)$ are from the Yoruba tribe, onequarter $66(25.3 \%)$ are from the Igbo tribe, $10(3.8 \%)$ are Hausa while 19 (7.3\%) are from other tribes. About 68\% (178) were Christians with majority 245(93.9\%) being single. Other demographics are summarized on Table 1. The respondents were well distributed among various health-related courses with pharmacy (31.4\%), nursing (31\%) and Medicine (21.1\%) having the largest distributions. About $90 \%$ (233) of the respondents were undergraduates while the remaining $10.7 \%$, comprised of postgraduate students on their MSc. and Ph.D. (Table 2).

\section{Effect of COVID-19 on Mental Health of Healthcare Students}

Table 3 shows the effect of COVID-19 on mental health of healthcare students. Most affirmed that they lack interest in activities and happenings around them (33.3\% strongly agreed, $19.5 \%$ agreed), majority (44.8\% strongly agreed, $19.5 \%$ agreed) are also afraid now more than often since there is no specific end to the pandemic. However, an appreciable number of the respondents (109) claimed to be always down, depressed and hopeless due to this pandemic

(Table 3). Overall, responses from majority of the 
Table 3. Effect of COVID-19 on mental health of healthcare students

\begin{tabular}{|c|c|c|c|c|c|c|c|}
\hline \multirow{3}{*}{\multicolumn{3}{|c|}{ Items }} & \multicolumn{5}{|c|}{$\begin{array}{l}\text { Responses }(\mathrm{N}=\mathbf{2 6 1}) \\
\text { Frequency (\%) }\end{array}$} \\
\hline & & & SA & $\mathbf{A}$ & $\mathbf{N}$ & $\mathbf{D}$ & SD \\
\hline & & & ALW & $\mathbf{0}$ & STM & $\mathbf{R}$ & NVR \\
\hline \multicolumn{3}{|c|}{ I lack interest in activities, hobbies or happenings around me } & $87(33.3)$ & $51(19.5)$ & $26(10.0)$ & $60(23.0)$ & $37(14.2)$ \\
\hline \multicolumn{3}{|c|}{$\begin{array}{l}\text { I am afraid now more often than not since there appears to be no } \\
\text { end in sight regarding this pandemic }\end{array}$} & $117(44.8)$ & $51(19.5)$ & $33(12.6)$ & $42(16.1)$ & 18(6.9) \\
\hline \multicolumn{3}{|c|}{\begin{tabular}{|l|} 
I feel down, depressed or hopeless \\
\end{tabular}} & 109(41.8) & $95(36.4)$ & $36(13.8)$ & $17(6.5)$ & $4(1.5)$ \\
\hline \multirow{2}{*}{$\begin{array}{l}\text { Effect on mental health } \\
\text { score }\end{array}$} & Score $>50 \%(\%)$ & $182(69.7)$ & & & & & \\
\hline & Score $<50 \%(\%)$ & $79(30.3)$ & & & & & \\
\hline
\end{tabular}

Key: $\mathrm{SA}=$ Strongly agree $\mathrm{A}=$ Agree, $\mathrm{N}=$ Neutral, $\mathrm{D}=$ Disagree, $\mathrm{SD}=$ Strongly disagree.

$\mathrm{ALW}=$ Always, $\mathrm{O}=$ Often, $\mathrm{STM}=$ Sometimes, $\mathrm{R}=$ Rarely, NVR= Never

Score $>50 \%=$ considerable effect, Score $<50 \%=$ no effect. F= Frequency

Table 4. Effect of COVID-19 on social life of healthcare students

\begin{tabular}{|c|c|c|c|c|c|c|c|}
\hline \multirow{2}{*}{\multicolumn{3}{|c|}{ Items }} & \multicolumn{5}{|c|}{ Responses $(\mathrm{N}=261)$} \\
\hline & & & SA & A & $\mathrm{N}$ & $\mathrm{D}$ & SD \\
\hline \multicolumn{3}{|c|}{ The pandemic has affected my art of socialization } & $135(51.7)$ & $61(23.4)$ & 19(7.3) & $36(13.8)$ & $10(3.8)$ \\
\hline \multicolumn{3}{|c|}{$\begin{array}{l}\text { I now have time for family and friends and this has helped in } \\
\text { boosting relationship }\end{array}$} & $48(18.4)$ & $64(24.5)$ & $40(15.3)$ & $22(8.4)$ & $87(33.3)$ \\
\hline \multicolumn{3}{|c|}{$\begin{array}{l}\text { Interaction on social media has conveniently replaced } \\
\text { conventional social activity for me }\end{array}$} & 109(41.8) & $95(36.4)$ & $36(13.8)$ & $17(6.5)$ & $4(1.5)$ \\
\hline \multirow{2}{*}{$\begin{array}{l}\text { Effect on social life } \\
\text { score }\end{array}$} & Score $>50 \%(\%)$ & $248(95.0)$ & & & & & \\
\hline & Score $<50 \%(\%)$ & $13(5.0)$ & & & & & \\
\hline
\end{tabular}

Key: $\mathrm{SA}=$ Strongly agree $\mathrm{A}=$ Agree, $\mathrm{N}=$ Neutral, $\mathrm{D}=$ Disagree, $\mathrm{SD}=$ Strongly disagree.

Score $>50 \%=$ considerable effect, Score $<50 \%=$ no effect. F= Frequency

Table 5. Effect of COVID-19 on safety of healthcare students

\begin{tabular}{|c|c|c|c|c|c|c|c|}
\hline \multirow{2}{*}{\multicolumn{3}{|c|}{ Items }} & \multicolumn{5}{|c|}{$\begin{array}{c}\text { Responses } \\
\text { Frequency (\%) }\end{array}$} \\
\hline & & & SA & $A$ & $\mathrm{~N}$ & $\mathrm{D}$ & SD \\
\hline \multicolumn{3}{|c|}{ I feel safer now since I stay at home almost all the time } & $19(7.3)$ & $93(35.6)$ & $54(20.7)$ & $34(13.0)$ & $61(23.4)$ \\
\hline \multicolumn{3}{|c|}{ Criminal activities are on the rise in my area and so I feel unsafe } & $61(23.4)$ & $71(27.2)$ & $28(10.7)$ & $55(21.1)$ & $46(17.6)$ \\
\hline \multicolumn{3}{|c|}{$\begin{array}{l}\text { I am afraid of going out to crowded places like markets for the } \\
\text { fear of contacting the virus }\end{array}$} & $87(33.3)$ & $71(27.2)$ & $26(10.0)$ & $38(14.6)$ & $39(14.9)$ \\
\hline \multirow{2}{*}{ Effect on safety score } & Score $>50 \%(\%)$ & $168(64.4)$ & & & & & \\
\hline & Score $<50 \%(\%)$ & $93(35.6)$ & & & & & \\
\hline
\end{tabular}

Key: $\mathrm{SA}=$ Strongly agree $\mathrm{A}=$ Agree, $\mathrm{N}=$ Neutral, $\mathrm{D}=$ Disagree, $\mathrm{SD}=$ Strongly disagree.

Score $>50 \%=$ considerable effect, Score $<50 \%=$ no effect. $F=$ Frequency

participants (69.7\%) had greater than 50\% perceived effect score showing a considerable effect of COVID-19 on the mental health compared to those $(30.3 \%)$ without a considerable effect (Table 3).

\section{Effect of COVID-19 on Social Life of Healthcare Students}

From the study, it was observed that the pandemic has affected the art of socialization of majority of the respondents $(196,75.1 \%)$ with only $112(42.9 \%)$ observed to have increase in relationship with their family members. Conversely, social media was perceived to have replaced conventional social activity for over three-quarter of the respondents (204) (Table 4). Overall, it was observed from the effect of COVID-19 on social life scores that $95 \%$ of the respondents were considerably affected (Table 4).

\section{Effect of COVID-19 on Safety of Healthcare Students}

From Table 5, 19 (7.3\%) students strongly agreed that they feel safer since they are at home, 93 (35.6\%) agreed and 61 (23.4\%) students strongly disagreed. More than half of the respondents (132) affirmed that criminal activities are on the rise in their area with a considerable number (158) being afraid of going out to crowded places due to fear of 
Table 6. Effect of COVID-19 on the formal learning of healthcare students

\begin{tabular}{|c|c|c|c|c|c|c|c|}
\hline \multirow{2}{*}{\multicolumn{3}{|c|}{ Items }} & \multicolumn{5}{|c|}{$\begin{array}{l}\text { Responses }(\mathrm{N}=261) \\
\text { Frequency (\%) }\end{array}$} \\
\hline & & & SA & A & $\mathbf{N}$ & D & SD \\
\hline \multicolumn{3}{|c|}{ I have more time to read my books and do research } & $73(28.0)$ & $81(31.0)$ & $40(15.3)$ & $26(10.0)$ & $41(15.7)$ \\
\hline \multicolumn{3}{|c|}{$\begin{array}{l}\text { Learning is very difficult at this time since there are a lot of } \\
\qquad \text { distractions at home }\end{array}$} & 108(41.4) & $110(42.1)$ & $16(6.1)$ & $16(6.1)$ & $11(4.2)$ \\
\hline \multicolumn{3}{|c|}{ Laziness is the order of the day for me since each day feels the same } & $97(37.2)$ & 109(41.8) & $21(8.0)$ & $27(10.3)$ & $7(2.7)$ \\
\hline \multirow{2}{*}{$\begin{array}{c}\text { Effect on Formal } \\
\text { learning score }\end{array}$} & Score $>50 \%(\%)$ & $252(96.6)$ & & & & & \\
\hline & Score $<50 \%(\%)$ & $9(3.4)$ & & & & & \\
\hline
\end{tabular}

Key: $\mathrm{SA}=$ Strongly agree $\mathrm{A}=$ Agree, $\mathrm{N}=$ Neutral, $\mathrm{D}=$ Disagree, $\mathrm{SD}=$ Strongly disagree.

Score $>50 \%=$ considerable effect, Score $<50 \%=$ no effect.

Table 7. Association between gender and perceived effect of COVID-19 on mental health

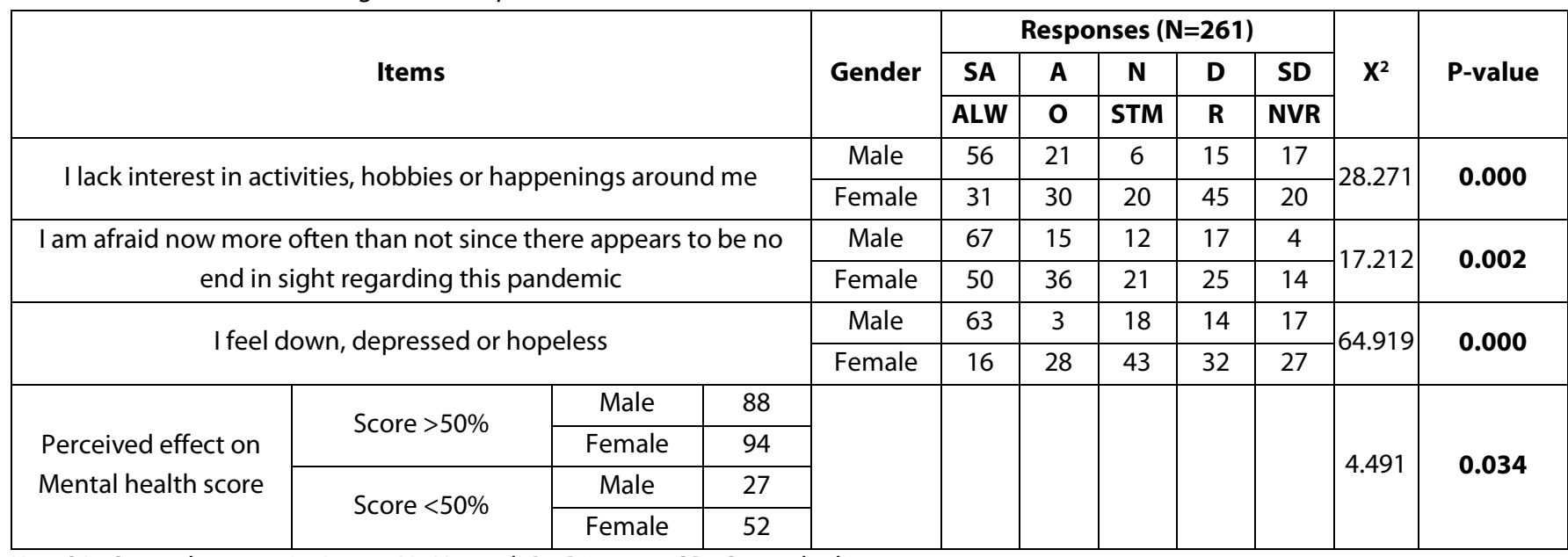

Key: $\mathrm{SA}=$ Strongly agree $\mathrm{A}=$ Agree, $\mathrm{N}=$ Neutral, $\mathrm{D}=$ Disagree, $\mathrm{SD}=$ Strongly disagree.

$\mathrm{ALW}=$ Always, $\mathrm{O}=$ Often, $\mathrm{STM}=$ Sometimes, $\mathrm{R}=$ Rarely, NVR= Never

Score $>50 \%=$ considerable effect, Score $<50 \%=$ no effect. F= Frequency

contracting the virus (Table 5). Overall, it was recorded that $64.4 \%$ (168) of the students perceived that COVID-19 has a considerable effect on safety (Table 5).

\section{Effect of COVID-19 on Formal Learning of Healthcare Students}

Table 6 shows that majority of the respondents' formal learning is affected by COVID-19 pandemic with 108 (41.4\%) strongly agreeing that learning is very difficult at this time of pandemic as there are a lot of distractions for them at home. Thirty-one percent of the respondents (81) agreed that they had more time to read their books and do research while $41.4 \%$ (109) agreed that laziness is the order of the day for them since each day feels the same (Table 6). Overall, a considerable effect of COVID-19 on the formal learning was recorded among 252 (96.6\%) of the respondents (Table 6).

\section{Association between Gender and Perceived Effect of COVID-19 on Mental Health}

Analysis was done to evaluate the relationship between gender and the perceived effect of COVID-19 on mental health of the respondents. It was deduced that there was an association between gender and responses to having a lack of interest in activities and hobbies $\left(X^{2}=28.271, p<0.001\right)$, gender and responses to being afraid now more than ever since there appears to be no end in sight regarding the pandemic $\left(X^{2}=17.212, p=0.002\right)$, gender and responses to feeling down, depressed and hopeless $\left(X^{2}=64.919, p<0.001\right)$

(Table 7). Also, there was an association between gender and the overall perceived effect of COVID-19 on the mental health $\left(X^{2}=4.491, p=0.034\right)$ (Table 7).

\section{Association between Gender and Perceived Effect of COVID-19 on Social Activity}

There was an association between gender and responses to pandemic affecting the art of socialization $\left(X^{2}=24.115\right.$, $p<0.001)$ and between gender and responses to now having time for family and friends $\left(X^{2}=63.010, p<0.001\right)$ (Table 8). However, there was no association between gender and responses to interaction on social media conveniently replacing conventional social activity $\left(X^{2}=8.837, p=0.065\right)$ as 
Table 8. Association between gender and perceived effect of COVID-19 on social activity

\begin{tabular}{|c|c|c|c|c|c|c|c|c|c|c|c|}
\hline \multirow{2}{*}{\multicolumn{4}{|c|}{ Items }} & \multirow{2}{*}{ Gender } & \multicolumn{5}{|c|}{ Responses (N=261) } & \multirow{2}{*}{$\mathbf{X}^{2}$} & \multirow{2}{*}{ P-value } \\
\hline & & & & & SA & A & $\mathbf{N}$ & D & SD & & \\
\hline \multirow{2}{*}{\multicolumn{4}{|c|}{ The pandemic has affected my art of socialization }} & Male & 78 & 19 & 8 & 7 & 3 & \multirow{2}{*}{24.115} & \multirow{2}{*}{0.000} \\
\hline & & & & Female & 57 & 42 & 11 & 29 & 7 & & \\
\hline \multirow{2}{*}{\multicolumn{4}{|c|}{$\begin{array}{l}\text { I now have time for family and friends and this has helped in } \\
\text { boosting relationship }\end{array}$}} & Male & 10 & 17 & 13 & 7 & 68 & \multirow{2}{*}{63.010} & \multirow{2}{*}{0.000} \\
\hline & & & & Female & 38 & 47 & 27 & 15 & 19 & & \\
\hline \multirow{2}{*}{\multicolumn{4}{|c|}{$\begin{array}{l}\text { Interaction on social media has conveniently replaced } \\
\text { conventional social activity for me }\end{array}$}} & Male & 50 & 48 & 8 & 7 & 2 & \multirow{2}{*}{8.837} & \multirow{2}{*}{0.065} \\
\hline & & & & Female & 59 & 47 & 28 & 10 & 2 & & \\
\hline \multirow{4}{*}{$\begin{array}{c}\text { Perceived effect on social } \\
\text { activity score }\end{array}$} & \multirow{2}{*}{ Score $>50 \%$} & Male & 111 & & & & & & & \multirow{4}{*}{0.981} & \multirow{4}{*}{0.322} \\
\hline & & Female & 137 & & & & & & & & \\
\hline & \multirow{2}{*}{ Score $<50 \%$} & Male & 4 & & & & & & & & \\
\hline & & Female & 9 & & & & & & & & \\
\hline
\end{tabular}

Key: $\mathrm{SA}=$ Strongly agree $\mathrm{A}=$ Agree, $\mathrm{N}=$ Neutral, $\mathrm{D}=$ Disagree, $\mathrm{SD}=$ Strongly disagree.

Score $>50 \%=$ considerable effect, Score $<50 \%=$ no effect. $F=$ Frequency

Table 9. Association between gender and perceived effect of COVID-19 on safety

\begin{tabular}{|c|c|c|c|c|c|c|c|c|c|c|c|}
\hline \multirow{2}{*}{\multicolumn{4}{|c|}{ Items }} & \multirow{2}{*}{ Gender } & \multicolumn{5}{|c|}{ Responses (N=261) } & \multirow{2}{*}{$\mathbf{X}^{2}$} & \multirow{2}{*}{ P-value } \\
\hline & & & & & SA & A & $\mathbf{N}$ & D & SD & & \\
\hline \multirow{2}{*}{\multicolumn{4}{|c|}{ I feel safer now since I stay at home almost all the time }} & Male & 4 & 63 & 18 & 14 & 16 & \multirow{2}{*}{35.746} & \multirow{2}{*}{0.000} \\
\hline & & & & Female & 15 & 30 & 36 & 20 & 45 & & \\
\hline \multirow{2}{*}{\multicolumn{4}{|c|}{ Criminal activities are on the rise in my area and I feel unsafe }} & Male & 51 & 24 & 9 & 20 & 11 & \multirow{2}{*}{52.247} & \multirow{2}{*}{0.000} \\
\hline & & & & Female & 10 & 47 & 19 & 35 & 35 & & \\
\hline \multirow{2}{*}{\multicolumn{4}{|c|}{$\begin{array}{l}\text { I am afraid of going out to crowded places like markets for the fear } \\
\text { of contacting the virus }\end{array}$}} & Male & 59 & 25 & 5 & 17 & 9 & \multirow{2}{*}{35.653} & \multirow{2}{*}{0.000} \\
\hline & & & & Female & 28 & 46 & 21 & 21 & 30 & & \\
\hline \multirow{4}{*}{$\begin{array}{l}\text { Perceived effect on safety } \\
\text { score }\end{array}$} & \multirow{2}{*}{ Score $>50 \%$} & Male & 86 & & & & & & & \multirow{4}{*}{9.722} & \multirow{4}{*}{0.002} \\
\hline & & Female & 82 & & & & & & & & \\
\hline & \multirow{2}{*}{ Score $<50 \%$} & Male & 29 & & & & & & & & \\
\hline & & Female & 64 & & & & & & & & \\
\hline
\end{tabular}

Key: $\mathrm{SA}=$ Strongly agree $\mathrm{A}=\mathrm{Agree}, \mathrm{N}=$ Neutral, $\mathrm{D}=$ Disagree, $\mathrm{SD}=$ Strongly disagree.

Score $>50 \%=$ considerable effect, Score $<50 \%=$ no effect. F $=$ Frequency

well as no association between gender and the overall effect on social activity scores $\left(X^{2}=0.981, p=0.322\right)$ (Table 8).

\section{Association between Gender and Perceived Effect of COVID-19 on Safety}

In this study, there was an association between gender and the responses to criminal activities being on the rise since the start of the pandemic $\left(X^{2}=52.247, p<0.001\right)$ (Table 9). There was also an association between gender and the overall perceived effect on safety scores $\left(X^{2}=9.722, p=\right.$ 0.002) (Table 9).

\section{Association between Gender and Perceived Effect of COVID-19 on Formal Learning}

There was an association recorded between gender and responses to laziness being the order of the day since each day feels the same $\left(X^{2}=26.590, p<0.001\right)$ (Table 10). However, there was no association between gender and responses to learning being difficult $\left(X^{2}=4.474, p=0.346\right)$ and there was no association between gender and the overall perceived effect on formal learning scores $\left(X^{2}=0.001\right.$, $p=0.981$ ) (Table 10).

\section{DISCUSSION}

\section{Effect of COVID-19 on Mental Health of Healthcare Students}

COVID-19 has been documented to bring about distress that can be psychological or social and this can affect mental health negatively [21]. This has triggered the need that mental health care should be a part of the National public health emergency system [21]. In this study, there was a remarkable considerable perceived effect of COVID-19 on the mental health of healthcare students. This result is similar to the result recorded by Zhang et al. [13] where a study carried out among college undergraduate students to evaluate their mental health during the COVID-19 era showed that more students experienced stress but the study involved students with disabilities. More studies on the 
Table 10. Association between gender and perceived effect of COVID-19 on formal learning of students

\begin{tabular}{|c|c|c|c|c|c|c|c|c|c|c|c|}
\hline \multirow{2}{*}{\multicolumn{4}{|c|}{ Items }} & \multirow{2}{*}{ Gender } & \multicolumn{5}{|c|}{ Responses $(\mathrm{N}=\mathbf{2 6 1})$} & \multirow{2}{*}{$\mathbf{X}^{2}$} & \multirow{2}{*}{ P-value } \\
\hline & & & & & SA & A & $\mathbf{N}$ & D & SD & & \\
\hline \multirow{2}{*}{\multicolumn{4}{|c|}{ I have more time to read my books and do research }} & Male & 61 & 19 & 11 & 6 & 18 & \multirow{2}{*}{69.261} & \multirow{2}{*}{0.000} \\
\hline & & & & Female & 12 & 62 & 29 & 20 & 23 & & \\
\hline \multirow{2}{*}{\multicolumn{4}{|c|}{$\begin{array}{l}\text { Learning is very difficult at this time since there are a lot of } \\
\qquad \text { distractions at home }\end{array}$}} & Male & 50 & 50 & 7 & 3 & 5 & \multirow{2}{*}{4.474} & \multirow{2}{*}{0.346} \\
\hline & & & & Female & 58 & 60 & 9 & 13 & 6 & & \\
\hline \multirow{2}{*}{\multicolumn{4}{|c|}{$\begin{array}{l}\text { Laziness is the order of the day for me since each day feels } \\
\text { the same }\end{array}$}} & Male & 61 & 36 & 10 & 5 & 36 & \multirow{2}{*}{26.590} & \multirow{2}{*}{0.000} \\
\hline & & & & Female & 36 & 73 & 11 & 22 & 4 & & \\
\hline \multirow{4}{*}{$\begin{array}{l}\text { Perceived effect on } \\
\text { formal learning score }\end{array}$} & \multirow{2}{*}{ Score $>50 \%$} & Male & 111 & & & & & & & \multirow{4}{*}{0.001} & \multirow{4}{*}{0.981} \\
\hline & & Female & 141 & & & & & & & & \\
\hline & \multirow{2}{*}{ Score $<50 \%$} & Male & 4 & & & & & & & & \\
\hline & & Female & 5 & & & & & & & & \\
\hline
\end{tabular}

Key: $\mathrm{SA}=$ Strongly agree $\mathrm{A}=$ Agree, $\mathrm{N}=$ Neutral, $\mathrm{D}=$ Disagree, $\mathrm{SD}=$ Strongly disagree.

Score $>50 \%=$ considerable effect, Score $<50 \%=$ no effect. $F=$ Frequency

effect of COVID-19 on the mental health of college students has been done in China [14,15], Greece [16] and India [17] and it was documented that the college students experienced increase in anxiety, and increased psychological impact. A contrasting study by Folk et al. [22] has also been documented that recorded that students' mental health was seemingly not affected since students showed resilience to distress and reported less loneliness. However, students with a history of stress exposure can express the exact opposite [23].

\section{Effect of COVID-19 on the Formal Learning of Healthcare Students}

In this study, most of the participants agreed that they had more time to do research and learning and this is mostly online since conventional formal learning has been suspended due to the pandemic. Online learning has increased significantly over the last 15 years [24]. This study has showed that with COVID-19, there was a seemingly increased accessibility to online learning since formal learning in classrooms has been suspended. Accessible education has been documented to contribute significantly to student wellbeing [13] and inaccessibility can contribute to potential stresses and concerns [25].

\section{Effect of COVID-19 on the Social Life of Healthcare Students}

COVID-19 was presumed to have a considerable effect on social life by the healthcare students in this study. This was shown by the strong agreement to the pandemic affecting art of socialization, increasing socialization with family members and friends and increasing the use of social media. These results are similar to what was documented by Chauhan and Shah [26] where $80 \%$ of the participants in the study agreed that there is a change in media consumption habits such that they use social media platforms such as WhatsApp, Facebook and Instagram to stay connected to friends, family and relatives. This study goes to confirm the effect of COVID-19 on the social life of students.

\section{Effect of COVID-19 on the Safety of Healthcare Students}

Due to the social distancing measures and lockdowns associated with the COVID-19 outbreak, the effects on human wellbeing including effects on crime and safety can be dramatic and unpredictable $[18,27]$. In this study there was a presumed effect on safety such that majority felt safer staying at home, criminal activities are on the rise and afraid of going out to the market places due to fear of contacting the virus. These findings are similar to those documented by Chauhan and Shah [26] and Ashby [18] where majority of the participants opted to buy more goods online than in stores due to fear of contacting the virus and that there was no significant change in the actual frequency of crime since the onset of COVID-19 pandemic respectively. However, another study by Halford et al. [28] carried out in the UK recorded that there is a decrease in crime rates such as inhouse robberies and pilfering in stores.

\section{Association between Gender and Perceived Effect of COVID-19 on Mental Health, Social Life, Safety and Formal Learning of Healthcare Students}

In this study, there was an association between gender and presumed effect on mental health, and safety but no significant association between gender and presumed effect on formal learning and social activity. This is similar to the study documented by Wang et al. [29] where it was stated that socio-demographic parameters including gender was associated with psychological impact of the virus on the study participants. In a study carried out by Liu et al. [9], it was documented that more women showed 
higher levels of post-traumatic stress. This could be due to the fact that China is one of the countries with majority of the cases of COVID-19. Studies carried out by Rossi et al. [11] and Qui et al. [10] in Italy and China respectively, showed that women including healthcare workers experienced mental health issues and higher significant psychological distress than their male colleagues. This implies that interventions focusing on improving mental health due to COVID-19 should be designed.

\section{Limitations}

This study had few limitations such as use of convenience sampling method which is associated with bias. The sample size used in this study was also small which will affect the generalizability of the results.

\section{CONCLUSION}

The COVID-19 pandemic has considerable effect on the mental health, formal learning, safety and social life of healthcare students. There is a need for interventions tailored to either augment the effects in terms of online learning or reduce the effects in terms of mental health.

\section{Practice Implications}

This study results show that there is a need to design interventions tailored towards the mental health of students.

\section{Recommendations}

More studies are required with a larger sample size to evaluate the effect of COVID-19 on healthcare students. Online learning is an area that needs to be explored for students to aid them to provide adequate learning environment during the COVID-19 era.

\section{DECLARATION OF CONFLICT OF INTEREST}

The authors received no financial support for the research and/or authorship of this article. There is no conflict of interest.

\section{REFERENCES}

1. World Health Organisation. Coronavirus pandemic. 2020. Available at: https://www.who.int/emergencies/diseases /novel-coronavirus-2019 (Accessed: June 6, 2020).

2. Chahrour M, Assi $S$, Bejjani $M$, et al. A Bibliometric Analysis of COVID-19 research activity: A call for increased output. Cureus J Med Sci. 2020; 12(3): 7357. (doi: 10.7759/cureus.7357).
3. Gorbalenya, A, Baker S, Baric R, et al. Severe acute respiratory syndrome-related coronavirus: classifying 2019-nCoV and naming it SARS-CoV-2. Nat Microbiol 2020; 5: 536-544. (doi: 10.1038/s41564-020-0695-z)

4. Shereen M, Khan S, Kazmi A, Bashir N, Siddique R. COVID19 infection: Origin, transmission, and characteristics of human coronaviruses. J Adv Research. 2020; 24: 91-8. (doi: 10.1016/j.jare.2020.03.005).

5. Umoh M, Nseobot I, Hamid D, et al. COVID-19 City Locked Down: Implications on Human Welfare in Developing Countries. Rochester, NY: Soc Sci Res Netwrk; 2020; Apr.

6. Igwe P. Coronavirus with looming global health and economic doom. Afr. Dev Inst Res Meth. 2020; 1(1): 1-6.

7. Sahu P. Closure of universities due to coronavirus disease (COVID-19): Impact on education and mental health of students and academic staff. Cureus J. Med Sci. 2020; 12(4): 7541. (doi: 10.7759/cureus.7541).

8. Haleem A, Javaid M, Vaishya R, Deshmukh S. Areas of academic research with the impact of COVID-19. Am J Emerg Med. 2020; 38(7): 1524-6. (doi: 10.1016/j.ajem.2020.04.022).

9. Liu N, Zhang F, Wei C, et al. Prevalence and predictors of PTSS during COVID-19 outbreak in China hardest-hit areas: Gender differences matter. Psych. Res. 2020; 287: 112921. (doi: 10.1016/j.psychres.2020.112921).

10. Qiu J, Shen B, Zhao M, Wang Z, Xie B, Xiu Y. A nationwide survey of psychological distress among Chinese people in the COVID-19 epidemic: Implications and policy recommendations. G Psych. 2020; 33: 19-21. (doi: 10.1136/gpsych-2020-100213).

11. Rossi R, Socci V, Pacitti F, et al. Mental health outcomes among frontline and second-line care workers during the coronavirus disease 2019 (COVID-19) pandemic in Italy. JAMA Netw Open. 2020; 3(5): 2010185. (doi: 10.1001/jamanetworkopen.2020.10185).

12. Talevi D, Socci V, Carai M, Carnaghi G, Faleri S, Pacitti F. Mental health outcomes of the COVID-19 pandemic. Gliesiti della salute mentale della pandemia di COVID-19. Rivista Psich. 2020; 55(3): 137-44. (doi: 10.1708/3382.33569).

13. Zhang $H$, Nurius $P$, Sefidgar $Y$ et al. How does COVID-19 impact students with disabilities/health concerns? 2020. Available at: http://arxiv.org/abs/2005.05438 (Accessed: June 1, 2020). 
14. Cao W, Fang Z, Hou G, et al. The psychological impact of the COVID-19 epidemic on college students in China. Psychiatry Res. 2020; 287: 112934. (doi: 10.1016/j.psychres.2020.112934).

15. Wang C, Zhao H. The Impact of COVID-19 on Anxiety in Chinese University Students. Front. Psychol. 2020; 11: 1168. (doi: 10.3389/fpsyg.2020.01168).

16. Kaparounaki C, Patasali M, Mousa D, Papadopoulou E, Papadopoulou K, Fountoulakis K. University students' mental health amidst the COVID-19 quarantine in Greece. Psych Res. 2020; 290: 113111. (doi: 10.1016/j.psychres.2020.113111).

17. Varshney M, Parel J, Raizada N, Sarin S. Initial psychological impact of COVID-19 and its correlates in Indian community: An online (FEEL-COVID) survey. PLOS ONE. 2020; 15(5): $233874 . \quad$ (doi: 10.1371/journal.pone.0233874).

18. Ashby MP. Initial evidence on the relationship between the coronavirus pandemic and crime in the United States. Crime Sci. 2020; 9: 6. (doi:10.1186/s40163-02000117-6).

19. Farrell G, Tilley N. Coronavirus: how crime changes during a lockdown. The Conversation. Available at: http://theconversation.com/coronavirus-how-crimechanges-during-a-lockdown-134948 (Accessed: June 1, 2020).

20. General Assembly of the World Medical Association. World Medical Association Declaration of Helsinki: ethical principles for medical research involving human subjects. J of Amer Col of Dent 2014; 81: 14. (doi: 10.1515/9783110208856.233).

21. Bao Y, Sun Y, Meng S, Shi J, Lu L. 2019-nCoV epidemic: address mental healthcare to empower society. The Lancet. 2020; 395(10224): 37-8. (doi: 10.1016/S01406736(20)30309-3).
22. Folk D, Okabe-Miyamoto K, Dunn E, Lyubomirsky S. Have Introverts or Extroverts Declined in Social Connection During the First Wave of COVID-19?: The Role of Extraversion. Collabra Psychology, 2020; 6(1): 37. (doi: http://doi.org/10.1525/collabra).

23. Bruce MS. Stress, adaptation, and disease. Allostasis and allostatic load. Ann N Y Acad Sci. 1998; 840: 33-44. (doi: 10.1111/j.1749-6632.1998.tb09546.x).

24. Phillips A, Terras K, Swinney L, Schneweis C. Online Disability Accommodations: Faculty Experiences at One Public University. J Postsec Edu Dis. 2012; 25(4): 331-44.

25. Ringland KE, Nicholas J, Korneld R, Lattie E, Mohr DC, Reddy M. Understanding mental ill-health as psychosocial disability: Implications for assistive technology. In The 21st International ACM SIGACCESS Conference on Computers and Accessibility 2019; 156170. (doi: 10.1145/3308561.3353785).

26. Chauhan DV, Shah HS. An empirical analysis into sentiments, media consumption habits and consumer behaviour during coronavirus (COVID-19) outbreak. 2020. Purakala with ISSN 0971-2143 is an UGC CARE Journal. 2020; 31(20): 353-78.

27. Bump PS. Analysis | Crime fell in a locked-down New York City - but less than you might think. Washington Post. Available at: https://www.washingtonpost.com/politics/ 2020/04/15/crime-fell-locked-down-new-york-city-butless-than-you-might-think/ (Accessed: June 3, 2020).

28. Halford E, Dixon A, Farrell G, Nalleson N, Tilley N. Crime and coronavirus: social distancing, lockdown, and the mobility elasticity of crime. Crime Sci. 2020; 9: 11 (doi: 10.1186/s40163-020-00121-w).

29. Wang C, Pan R, Wan X, et al. Immediate psychological responses and associated factors during the initial stage of the 2019 coronavirus disease (COVID-19) epidemic among the general population in China. Int J Environ Res Public Health. 2020; 17(5): 1729. 